\title{
Biostratigraphy and Sequence Stratigraphy of Paleogene Deposits in Central Kopet-Dagh Basin (NE of Iran)
}

\author{
Batool Rivandi, ${ }^{1}$ Mohammad Vahidinia, ${ }^{1}$ Mehdi Nadjafi, ${ }^{1}$ \\ Asadollah Mahboubi, ${ }^{1}$ and Abbas Sadeghi ${ }^{2}$ \\ ${ }^{1}$ Department of Geology, Faculty of Science, Ferdowsi University of Mashhad, Mashhad, Iran \\ ${ }^{2}$ Department of Geology, Faculty of Science, Shahid Behshti University, Tehran, Iran
}

Correspondence should be addressed to Batool Rivandi; ba_rivandi@yahoo.com

Received 14 May 2013; Accepted 7 August 2013

Academic Editor: Atle Nesje

Copyright (C) 2013 Batool Rivandi et al. This is an open access article distributed under the Creative Commons Attribution License, which permits unrestricted use, distribution, and reproduction in any medium, provided the original work is properly cited.

In this paper, the biostratigraphy and sequence stratigraphy of marine Paleogene deposits from the Kopet-Dagh basin (NE of Iran) are described. Particularly the absence of Morozovella genus is discussed. In addition, the Paleocene/Eocene boundary has been studied in detail using the record of planktonic and larger benthic foraminifera. This boundary is located probably within a thin red horizon $(\sim 10-15 \mathrm{~cm})$ representing a paleosoil. Close to this boundary is located the base of the calcareous test dissolution interval, with the dominance of agglutinated benthic foraminifera and with a sudden decrease in the richness of benthic foraminiferal species. Biostratigraphic studies led to the identification of 33 genera of larger benthic foraminifera and 5 genera of planktonic foraminifera. Petrographical studies indicate that these sediments, consisting of four carbonate lithofacies ( 15 subfacies), may have been deposited on a shallow carbonate platform (ramp type). These lithofacies have been deposited in open marine, shoal, lagoon, and tidal flat environmental conditions. Sequence stratigraphic analysis led to the identification of four third-order depositional sequences. The interpreted sea-level curve in the Kopet-Dagh basin can be correlated with Paleocene-Eocene global curves, with a sea-level fall in the latest Paleocene, followed by a sea-level rise in the earliest Eocene.

\section{Introduction}

Paleogene, as a climatically highly dynamic period, is connecting the ice-free world of the Cretaceous to the glacially dominated world of the Neogene [1]. An abrupt climate warming of 5 to 10 degrees at the Paleocene/Eocene boundary, known as the Paleocene-Eocene Thermal Maximum (PETM), occurred approximately $55.5 \mathrm{Ma}$ ago [1]. It has been mainly linked to the catastrophic release of carbon from seafloor methane hydrate reservoirs (e.g., [2]). Remarkable stable oxygen and carbon isotope excursions have been detected in Antarctic waters near the end of the Paleocene ( $57.33 \mathrm{Ma}$ ago), indicating rapid global warming and oceanographic changes that caused one of the largest deep-sea benthic extinction of the past 90 million years [3]. Despite the lots of studies focused on the Paleocene/Eocene boundary, yet little is known about it in shallow-water setting. During the early Paleogene, the morozovellids and acarininids were immensely successful shallow-dwelling groups. They were well-known surface dwellers within the tropical and subtropical latitudes. Morozovella and Acarinina had similar ecological preferences, occupying the warm, and shallow, mixed layer of the oceans. They had a symbiotic relationship with algae [4-7]. Many biostratigraphers used to place the $\mathrm{P} / \mathrm{E}$ boundary at the extinction of Morozovella velascoensis, an event that marks the P5/P6 boundary [8]. However, the last occurrence (LO) of M. velascoensis appears to be diachronous; moreover, this species is not present in high latitudes or in shallow-water sections [9]. The extinction of Morozovella and large acarininids is an important event in the history of Cenozoic planktonic foraminifera but it has not been enough studied. The presence of Morozovella genus depends on climatic, marine currents and facies changes. It also depends on sedimentation and diagenetic processes. This study explores the biostratigraphy and sequence stratigraphy of the Chehel-Kaman Formation in central Kopet-Dagh basin using planktonic (without any Morozovella), agglutinated, and larger benthic foraminifera. larger benthic foraminifera 
(LBF) are major components of many Paleogene carbonate platforms around the world particularly in Paratethys realm. They are photosymbiotic organisms and lived in warm, oligotrophic, and shallow waters within the photic zone. Many works have been focused on Paleocene/Eocene boundary, but preboundary sediments (Late Paleocene) still needs to be studied more in detail especially in shallow-water settings.

\section{Geological Setting}

The Kopet Dagh as an inverted basin [10] is extended from the east of the Caspian Sea to NE Iran, north Afghanistan and Turkmenistan $[11,12]$. Following the closure of PalaeoTethys in the Middle Triassic [13] and the opening of NeoTethys during Early to Middle Jurassic [12], the Kopet Dagh basin formed during Early to Middle Jurassic [14]. Relatively continuous sedimentation took place from the Jurassic to the Neogene in the Kopet-Dagh basin $[11,15]$. This sedimentation was recorded by five major transgressive-regressive sequences [16]. Close to the end of Cretaceous period and beginning of Paleocene, the epicontinental sea regressed toward the northwest and a thick interval of red bed and siliciclastic sediments in early Paleocene age were deposited in fluvial environments (Pesteligh Formation) [16]. During the late Paleocene, the sea level rose rapidly with abrupt shifting of potential siliciclastic point sources toward the central and eastern parts of the basin. This transgression allowed carbonates of the Chehel-Kaman Formation to be deposited [16-18]. Kopet-Dagh basin is very important because it hosts the giant Khangiran and Gonbadli gas fields with the upper Paleocene carbonate in this basin representing one of the producing intervals. Chehel-Kaman Formation with the age of Paleogene is an important formation in Kopeh-Dagh basin at northeastern of Iran.

2.1. Material and Method. The present study is based on 1 stratigraphic section (Karnaveh section) in Kopet-Dagh basin which is well exposed (Figures 1 and 2). For analyzing planktonic and benthonic foraminifers of the studied section, 230 samples (each about $1 \mathrm{~kg}$ ) were picked out. In order to identify sedimentary structures and microfossil associations, a total of 49 thin sections from calcareous units were studied using a microscope. In order to determine biozones we used of Planktonic foraminifera see; Permoli et al. [19], and SerraKiel et al. [20]. Thin sections were stained by Alizarin red $S$ [21] and were studied using standard petrographic microscope techniques. Carbonate rocks were classified according to Dunham's carbonate classification (1962) and siliciclastic rocks were classified based on Folk's classification (1980). Microfacies analysis was carried out using standard models of Wilson [22] and Flugel [23]. Sequence stratigraphy was interpreted by analyzing surface and lithofacies studies. Carbonate rocks are dominant in Chehel-Kaman Formation; however, in central and western parts of Kopet-Dagh basin this formation mainly consists of shale and marl (open marine shale) with planktonic foraminifera. The larger benthic foraminifera are abundant in the East basin. Our studies show that KopetDagh basin in the West is deeper than in the East.

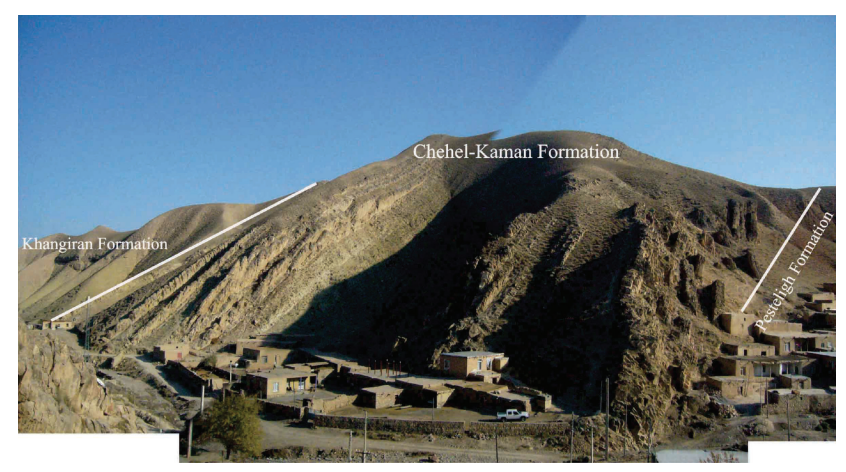

FIGURE 1: Outcrop photo of Chehel-Kaman Formation.

\section{Results}

3.1. Lithostratigraphy. Chehel-Kaman Formation in the Kopet-Dagh basin is mainly composed of limestones, dolomites, and interbeds of marls, shales, and evaporites. It conformably overlies the siliciclastic sediments of Pestehligh and underlies the olive shale of Khangiran Formation. Lithostratigraphic studies of Chehel-Kaman Formation show that this formation can be divided into 5 units. In Figures 3 and 4 some outcrop features of Chehel-Kaman Formation are shown.

3.2. Microfacies and Sequence Stratigraphy. Based on petrographic studies 15 carbonate microfacies were recognized in limestone of Chehel-Kaman Formation. These microfacies are grouped into 4 facies association (A, B, C, and D). In addition to these lithofacies, there are two siliciclastic lithofacies consisting of calcareous shale (marl) and calcite-cemented sandstone (facies E and F). The four carbonate lithofacies which are recognized across the outcrops of ChehelKaman Formation are (a) quartz-bioclastic mudstones to packstones, (b) bioclast-ooid-pelloid-intraclast grainstones to grainstones-packstones, (c) bioclast-pelloid packstones to wackestones, and (d) dolomudstones-mudstones to boundstones facies with evaporate components. They represent respectively open-marine, shoal, semirestricted lagoon, upper intertidal, and tidal-flat subenvironments within a shallow-marine carbonate ramp depositional setting.

3.3. Qz-Bioclastic Mudstones to Packstones (Facies A). This facies is divided into 2 subfacies mainly composed by bryozoans, echinoderms, and fragments of foraminifera (Rotaliids), indicating deposition in an open marine setting. Both subfacies are gray to light, thin to medium bedded limestones along the outcrop. (A1) Qz bioclast packstone subfacies contains 50\% Rotaliidae [23] (range diameter from 0.1 to $0.3 \mathrm{~mm}$ ) and other benthic foraminifera, bryozoans, echinoid, and brachiopod debris. The matrix consists of dark gray carbonatic mud (Figure 5(a)). (A2) Bioclast wackestone subfacies (Figure 5(b)) is similar to A1 subfacies but with less grains. The size of fragment is between 0.5 and $2 \mathrm{~mm}$.

This facies is deposited in relatively deep water, under low-energy environment (open marine).

3.4. Ooid-Pelloid-Bioclast-Intraclast Grainstones to Grainstones-Packstones (Facies B). This facies can be subdivided 


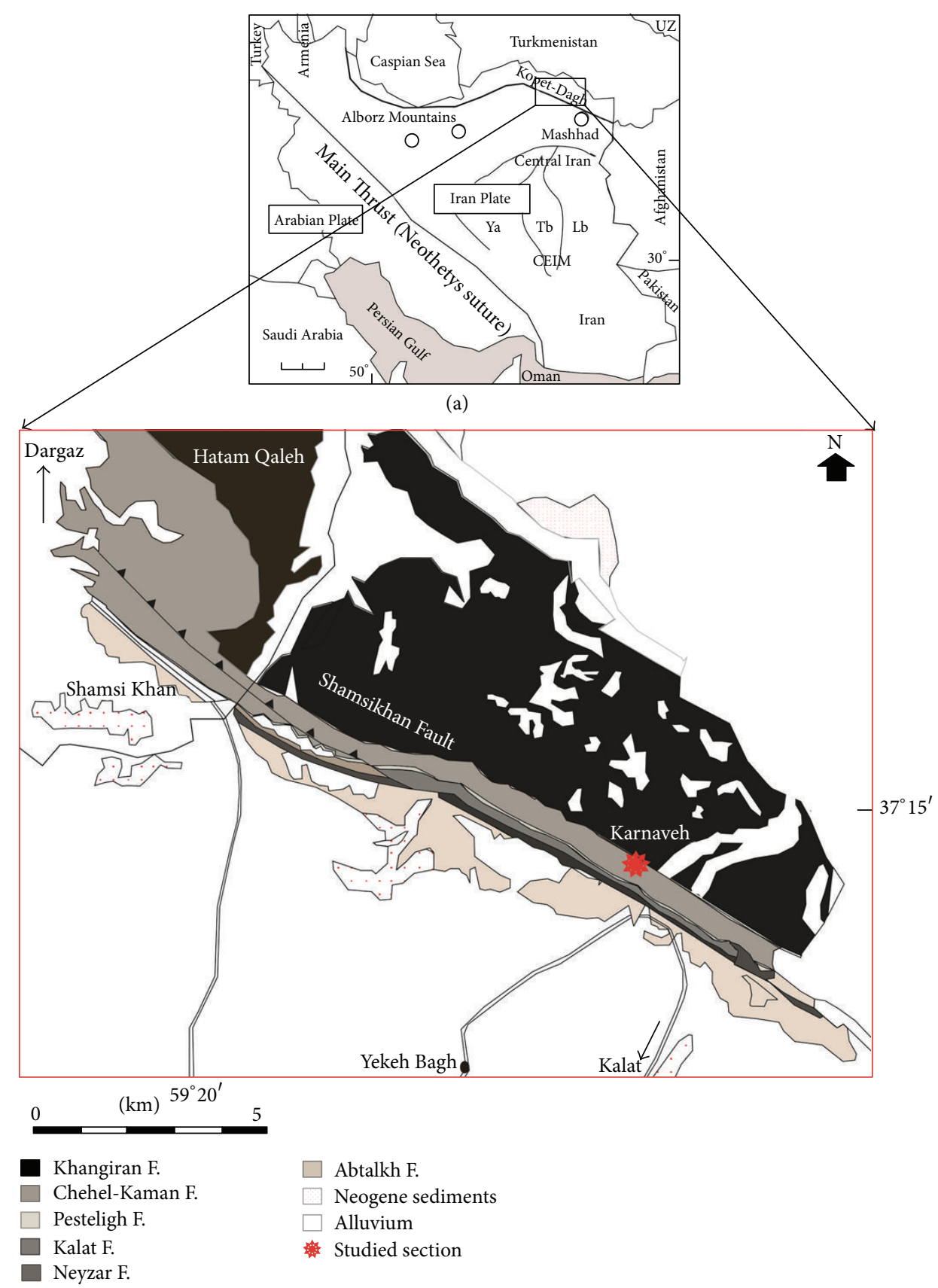

(b)

Figure 2: (a) Structural geology and geography maps of Iran showing the main sutures, structural units, and geographic areas (redrawn from [31]). AR: Armenia, AZ: Azerbaijan, UZ: Uzbekistan, Yb: Yazd Block, Tb: Tabas Block, Lb: Lut Block, CEIM: Central-East Iranian microcontinent. (b) Location map of the Chehel-Kaman Formation at Karnaveh section.

into 3 subfacies. The main components are ooid, red algae together with bivalve, bryozoans, echinoderm, brachiopods, and foraminifera. The skeletal grain size is usually large. Along the outcrop belt this facies is characterized by medium-to-thick bedding, light gray in color, and it displays cross-bedding and cross-lamination. The subfacies are (B1) bioclast-peloidal grainstones containing $45 \%$ peloid ( 0.3 to $0.5 \mathrm{~mm}$ ) and $3 \%$ benthic foraminifera ( 0.5 to $1 \mathrm{~mm}$ ). There is minor amount of echinoids and brachiopods fragments (less than 2\%) (Figure 5(c)); (B2) oolitic grainstone subfacies (Figure 5(d)) characterized by an abundance of ooid and minor amounts of open marine fauna connected by sparite cement. Many ooids have a concentric fabric whereas some have a radial fabric. Cores of ooids consist of foraminifera, bivalve, echinoids, and quartz grains. The ooid average size is $0.7 \mathrm{~mm}$. Some grains, such as bivalve fragments and micrite envelopes, are developed; (B3) intraclast-miliolid-pelloidal packstone-grainstone subfacies (Figure 5(e)) containing 40\% 

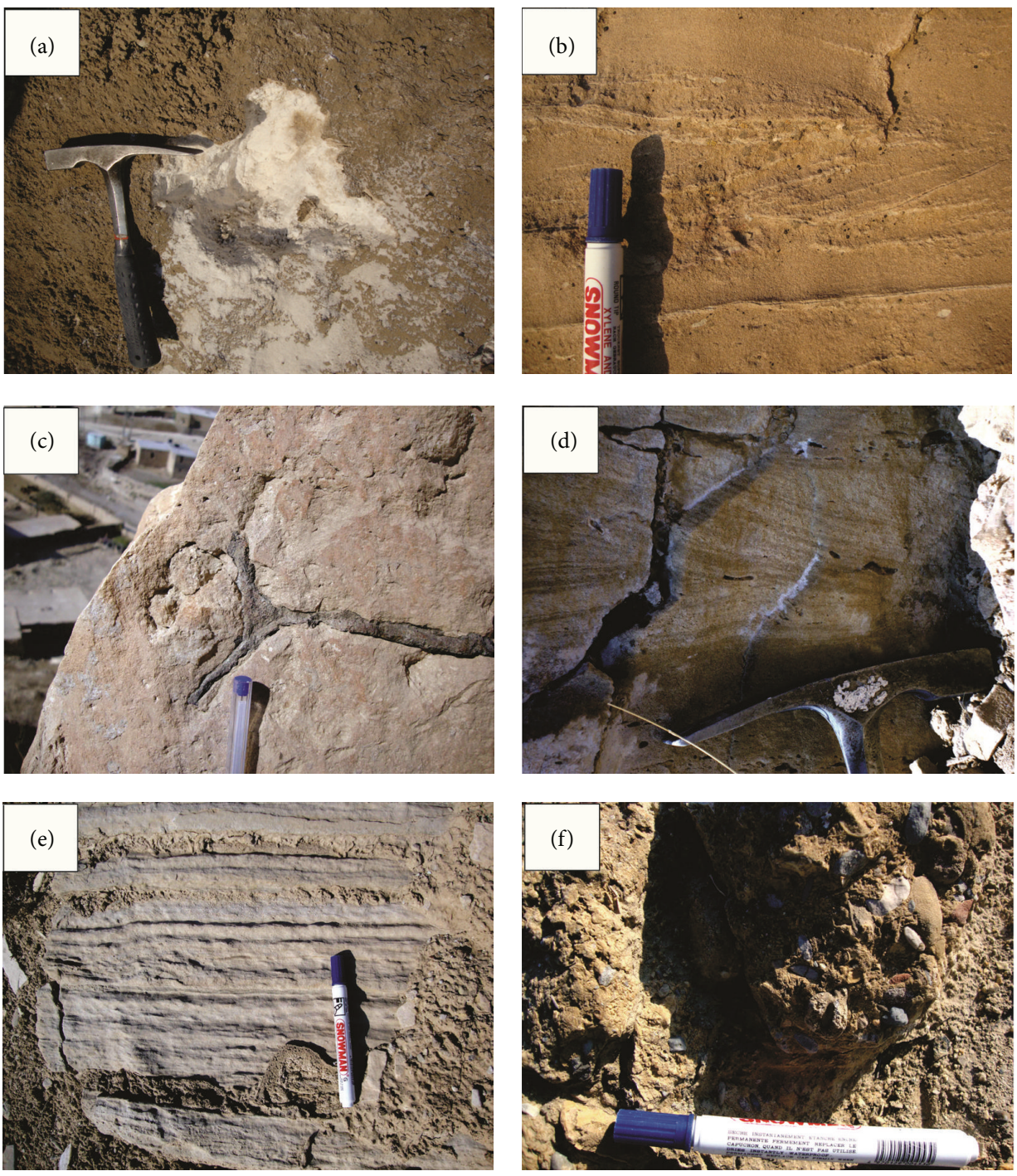

Figure 3: (a) Gypsum with radial growth that has been seen in the gradual transition Pesteligh To Chehel-Kaman formations. (b) Crosslaminated. (c) Trace fossils (Thalassinoides) in sandy limestone. (d) Herringbone cross-bedding structure that formed at least two surfaces, and it indicates tidal flat sediments. (e) Horizontal lamination structure in carbonate sequenc. (f) Calcareous Conglomerate that is formed of various grains.

peloid, $20 \%$ miliolids, and $10 \%$ intraclasts. Average diameter of peloids is $0.1 \mathrm{~mm}$. Intraclasts contain a variety of bioclasts that includes bivalves, benthic foraminifera, and detrital quartz grains. This facies comprises a mediumbedded succession of gray bioclastic calcarenite characterized by sedimentary structures such as cross-bedding and crosslamination. This facies is mostly mud free which can confirm the high energy sedimentary environment.

3.5. Bioclast-Peloid Packstones to Wackestones (Facies C). This facies consists of 3 subfacies containing high percentages of grains. In the outcrop this lithofacies is generally light gray to light tan. The subfacies are $(\mathrm{Cl})$ bioclastic packstones (Figure 5(f)) characterized by the abundance of skeletal grains such as green algae $(3 \%)$, benthic foraminifera such as textularia and miliolids (35\%), and minor amount $(2 \%)$ of brachiopods and bivalves. Nonskeletal grains are represented by peloid and detrital quartz; (C2) peloidal packstone subfacies (Figure $5(\mathrm{~g})$ ) containing $30 \%$ peloids and $5 \%$ echinoderms. The diameter of pellets ranges from 0.05 to $0.2 \mathrm{~mm}$; (C3) bioclastic wackestone (Figure 5(h)) consisting of minor amount of bioclastic components (green algae, miliolids, and textularia) and detrital quartz. This facies is interpreted as deposited in lagoonal environment.

\subsection{Dolomudstone-Mudstone to Boundstone with Evaporate} Component (D). This facies is subdivided into 3 subfacies D1, D2, and D3 and is interpreted as the most landward of the carbonate lithofacies. This facies presents thin-to-medium beds of yellow color. The subfacies are (D1) dolomudstone (Figure 6(a)) containing very fine crystalline dolomite. This subfacies is almost barren with scattered fenestral fabric. Few ostracods have been observed; (D2) sandy mudstone (Figure 6(b)) consisting of quartz grain in mud matrix. This 

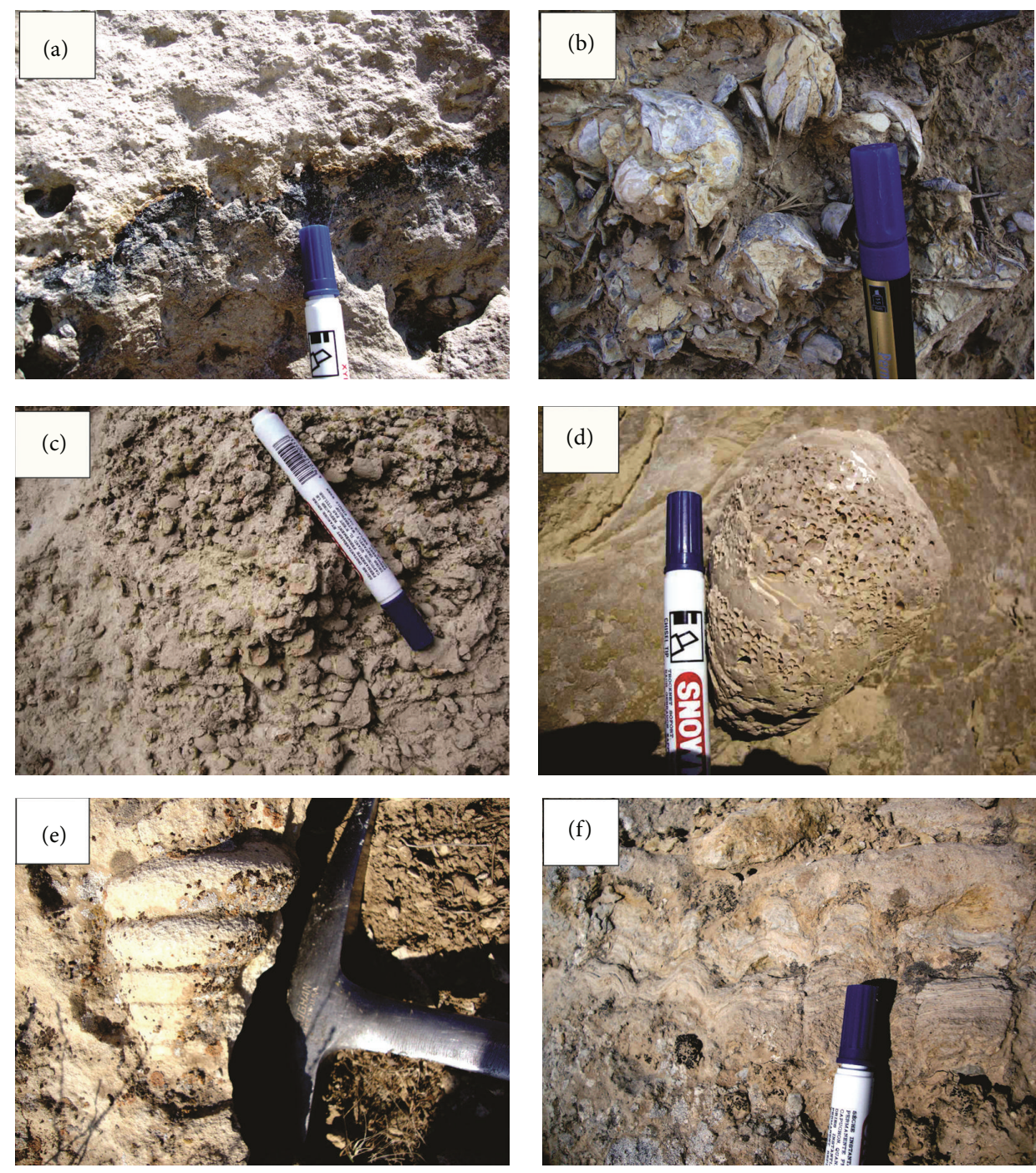

Figure 4: (a) Thin Paleosol horizon along with the sandy limestones on the top of Chehel-Kaman Formation that considered P/E boundary. It can be traced laterally for ten kilometers. (b) Shell beds of bivalve. (c) Shell beds of gastropods (d). (e) There are large size macrofossils (bivalve) and gastropods in carbonate succession. (f) Stromatolite boundstone.

subfacies has $15 \%$ porosity apparently formed by dissolution in late stage of diagenesis. The presence of fenestral fabric and evaporates indicates that this facies was deposited in an upper intertidal environment; (D3) laminated stromatolitic boundstone subfacies with significant amount of algal fragments and intraclasts that have been derived from fragmentation of stromatolites. Along the outcrop belt, this subfacies is characterized by thin irregular-to-regular laminated strata.

3.7. Shale and Calcareous Shale (E). Facies (E) consists of thin- to medium-thick beds of calcareous shale (marl) alternated to limestones along all of the sections. This facies can be divided into two subfacies: (E1) subfacies is generally thinto medium-thick green to gray calcareous shale that contains benthic foraminifera and ostracods; (E2) subfacies is containing gray calcareous shale with thin laminated beds and no fossils content. Moreover in (E2) subfacies, association of gypsum crystals and beds can be observed. On the base of sedimnetological and compositional features, the shales with benthic foraminifera were deposited in an outer ramp setting whereas gray calcareous shale with evaporate sediments and no fossils was deposited in a restricted lagoonal inner ramp.

\subsection{Calcareous Sandstone and Calcareous Conglomerate} Facies $(F)$. This facies consists of two subfacies. F1 is mediumto-thin bedded calcareous sandstone (Figure 6(c)) with trace fossils (Thalassinoides) and macrofossils (bivalves). These deposits are gray to tan in color and have cross-lamination. This facies is interpreted as deposited in a shoreline environment. (F2) subfacies is represented by calcareous conglomerate (Figure 6(d)) with clasts from older formations such as Tirgan or Mozduran Formations.

3.9. Sequence Stratigraphy. The upper Paleocene and lower Eocene interval consists of four depositional sequences (DS1, 

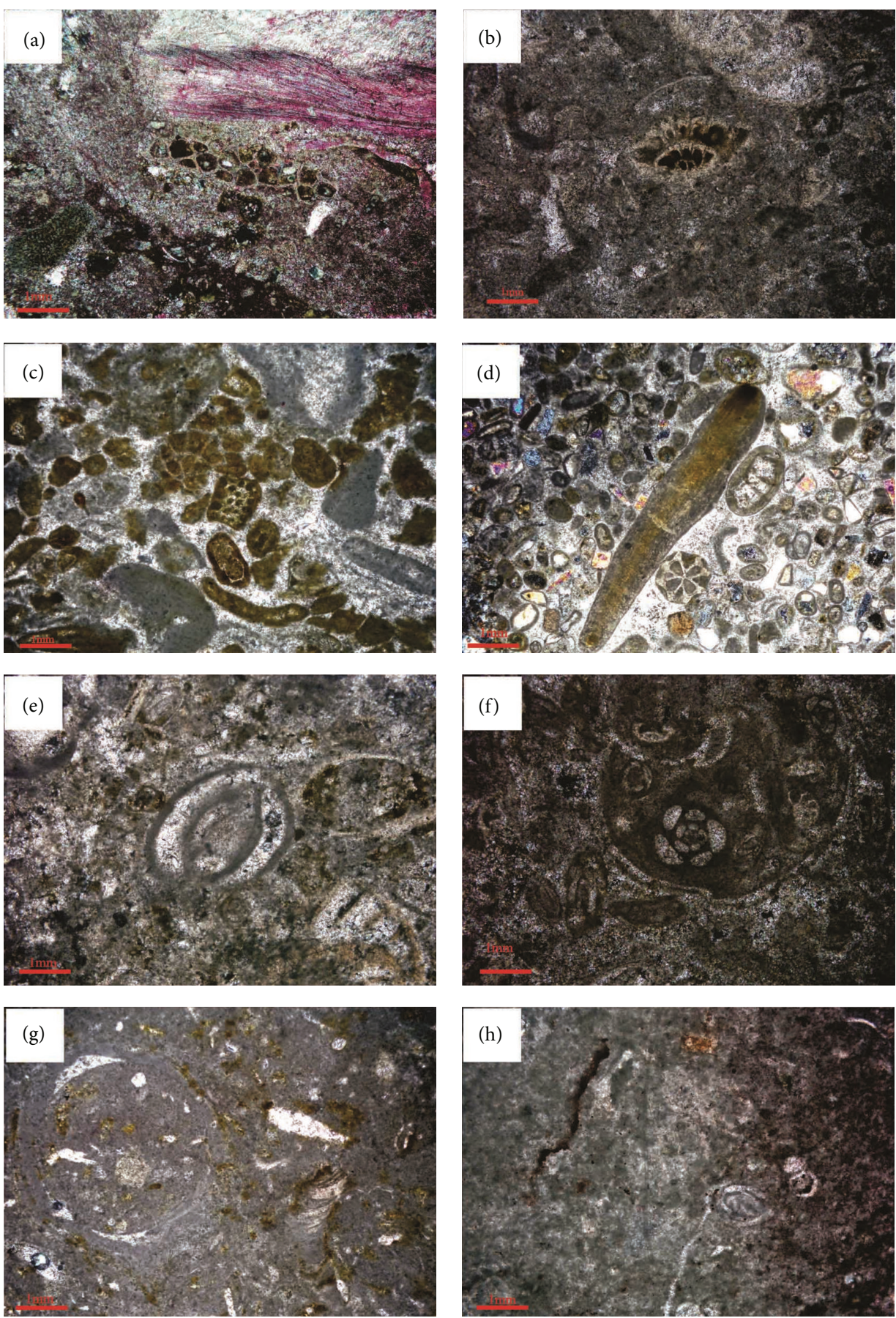

FIGURE 5: Microfacies of facies (A): (a) Qz bioclast packstone (subfacies A1) and (b) bioclast wackestone (subfacies A2). Microfacies of facies (B): (c) bioclast pelloid grainstone (subfacies B1), (d) ooid grainstone (subfacies B2), and (e) intramiliolid-pellolid packstone grainstone (subfacies B3). Microfacies (C): (f) bioclast packstone (subfacies C1), (g) pelloid packstone (subfacies C2), and (h) bioclast wackestone (subfacies C3).

DS2, DS3, and DS4), respectively, bounded by type 2 (within the top of underlying Pestehleigh Formation), type 1, type 1, and type 2 sequence boundaries, (Figure 7). Depositional sequence 1 (DS1) is the lowest depositional sequence. It is a fluvial depositional system [16] and its base lies just beneath the top of Pestehleigh Formation early Paleocene age in. This sequence starts with transgressive system tract deposition
(TST) that mostly consists of intertidal lithofacies (shale, gypsum, evaporate and deposition) and pass upward into lagoon lithofacies. High stand system tract (HST) deposition occurred after early eustatic fall. HST is a siliciclastic interval that ended with a conglomerate. It can be considered as a sequence boundary type1 (SB1). Depositional sequence 2 (DS2) is associated with a rapid sea level rise that led to 

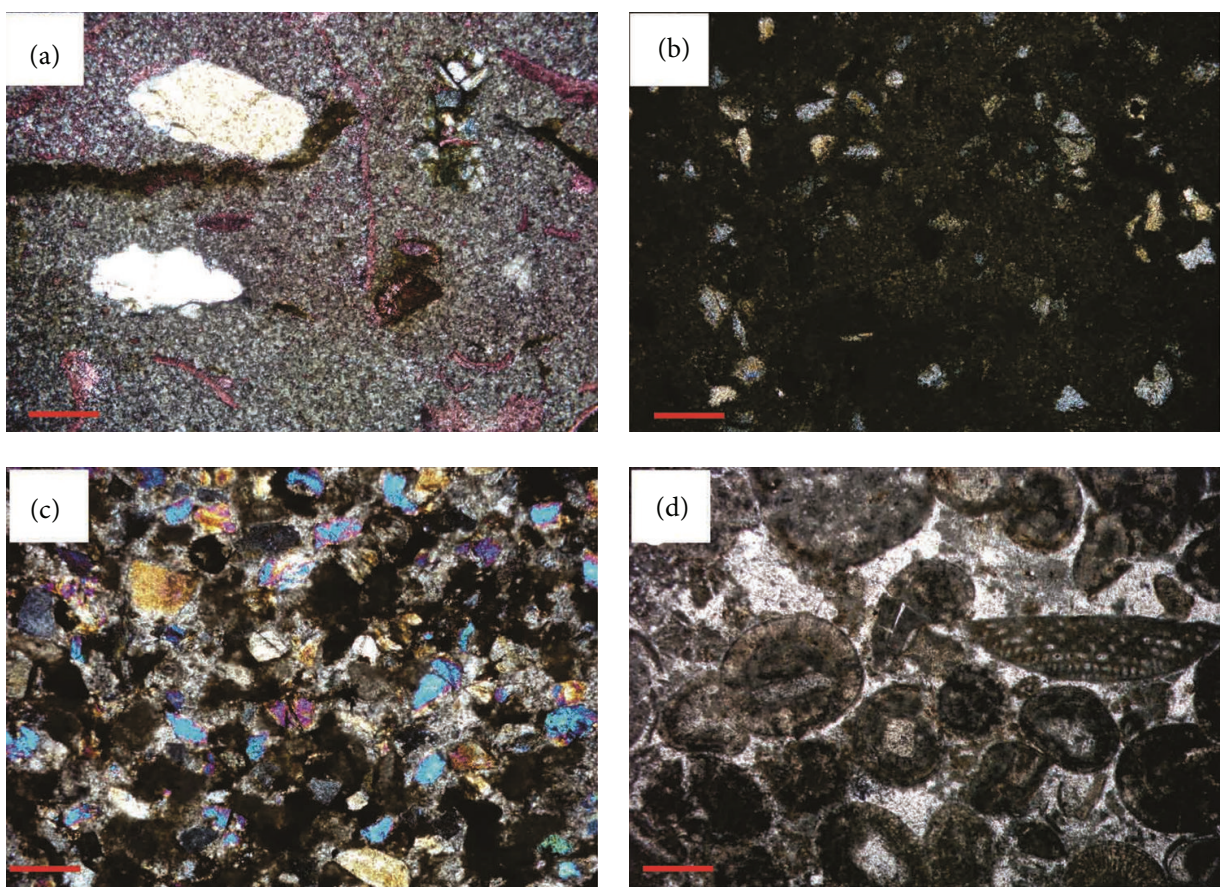

Figure 6: Microfacies (D): (a) dolomudstone (subfacies D1) and (b) Qz mudstone (subfacies D2). Microfacies (F): (c) Calcareous sandstone (subfacies F1) and (d) Calcareous conglomerate (subfacies F2).

the deposition of the carbonate sequence forming the transgressive system tract. Within this HST sequence the deposition of Shale and Marl of facies E and F took place. Also this sequence ended with a paleosol horizon and river channel sediments (conglomerate), which represents a sequence boundary type 1 . The paleosol is interpreted as formed during a major sea level fall in the latest Paleocene. The conglomerate is interpreted as channel-fill deposits. The Paleocene-Eocene boundary might correspond to this red paleosol horizon $(\sim 10-15 \mathrm{~cm})$ within this Paleogene succession. Depositional sequence 3 (DS3) contains TST with the deposition of shales and marls having planktonic foraminifera, and HST in this sequence is associated with sandstone and sandy carbonate intervals. Shales and marls in this sequence were deposited in open marine setting and consist mainly of planktonic foraminifera. Depositional sequence 4 (DS4) started with deposition of olive shale and marls belonging to the Khangiran Formation. Sea level changes during the late Danian/early Ypresian in the Kopet-Dagh basin are comparable to global changes proposed by Haq et al. [24], with minor differences related to local and regional geological events. The most important diagenetic processes affecting the limestones of Chehel-Kaman Formation are micritization, cementation, compaction (physical and chemical), neomorphism, dissolution, fracturing, and formation of calcite veins, silicification, and dolomitization.

3.10. Biostratigraphy. Pervious biostratigraphic studies (e.g., $[15,25])$ have shown that the Chehel-Kaman Formation was deposited during the late Paleocene (Thanetian). Yet, very few biostratigraphic studies have been done on Paleogene sediments in this basin. Therefore, it is important to investigate more in detail these sequences from the Kopet-Dagh basin in order to solve some biostratigraphic problems. Based on this study it might be probable that the Danian/Selandian boundary coincides with the interruption of carbonate deposition and the shift to siliciclastic sedimentation. A major fall in relative sea level during the late Danian led to the disappearance of bryozoans. There is a few glauconites in the last deposition of Danian interval in these sediments.

The following 5 genera and 9 species of planktonic foraminifera were identified (Figure 8) in the studied section: Parasubbotina varianta, Parasubbotina inaequispira, Subbotina eocaena, Globanomalina ovalis, Globanomalina australiformis, Globanomalina compressa, Globanomalina ehrenbergi, Globanomalina imitate, Globanomalina chapmani, Pseudohastigerina wilcoxensis, and Chiloguembelina trinitatensis.

Agglutinated foraminiferal assemblages of shale and marl samples have been also studied. Seven species have been identified: Clavulinoides aspera, Clavulinoides trilatera, Clavulinoides amorpha, Clavulinoides angularis, Marssonella cf. nammalensis, Marssonella oxycona, and Spiroplectammina carinata. The foraminifera are not generally well preserved and commonly recrystallized and filled with sparry calcite. While deep-sea benthic foraminifera suffered major extinction across the PETM, benthic foraminifera from marginal and epicontinental basins show less extinction and suffer only temporary assemblage changes. In shallow-water settings, increased biological productivity and anoxia at the seafloor have been documented across the PETM (e.g., [26-29]). An abrupt decrease in diversity close to the P/E boundary at the Chehel-Kaman Formation coincides with an increase in the percentage of certain agglutinated taxa, indicating environmental stress (intense $\mathrm{CaCO}_{3}$ dissolution, high temperature, 

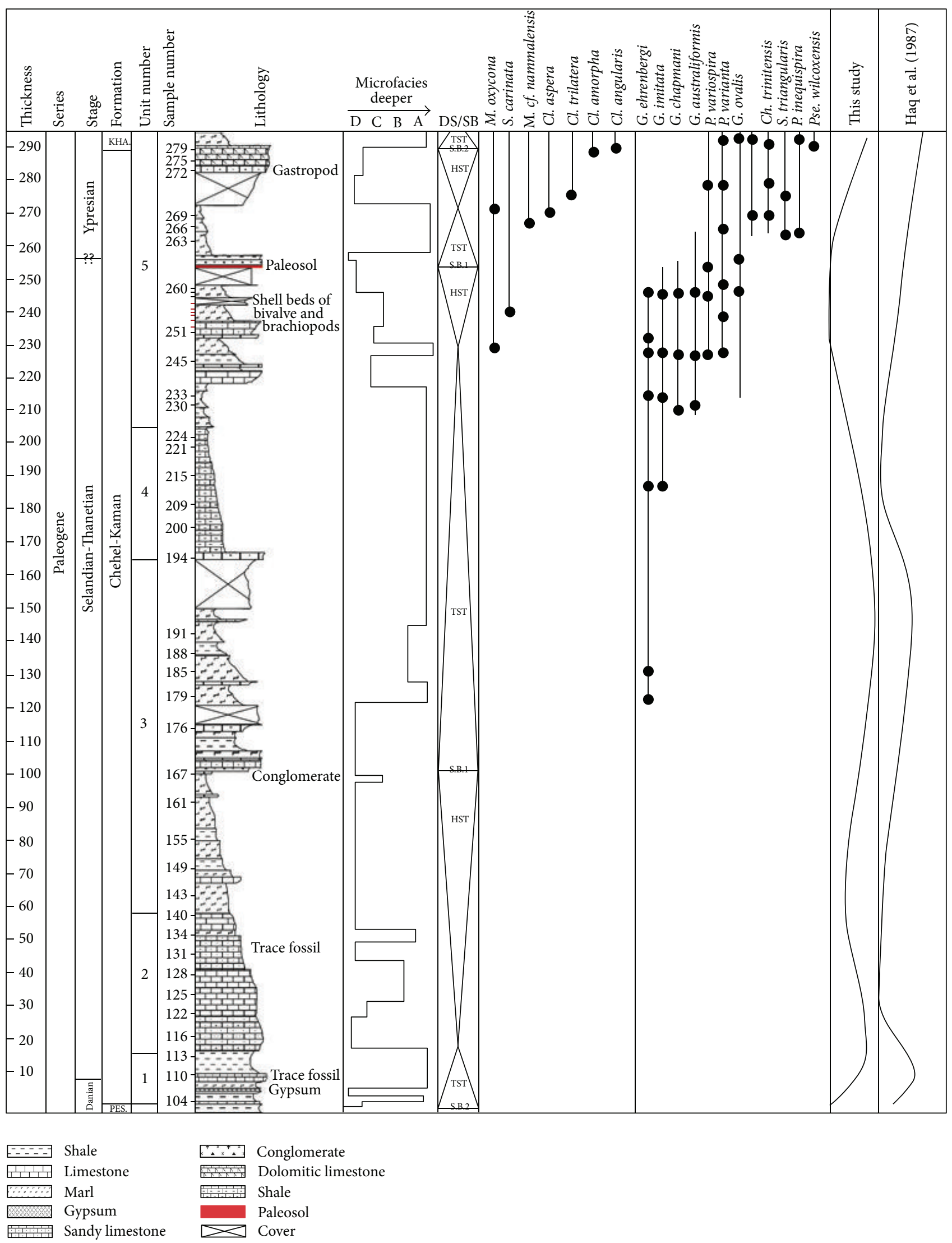

FIgURE 7: Lithostratigraphic, microfacies, and sequence stratigraphy of Chehel-Kaman Formation in Central Kopet-Dagh basin. 


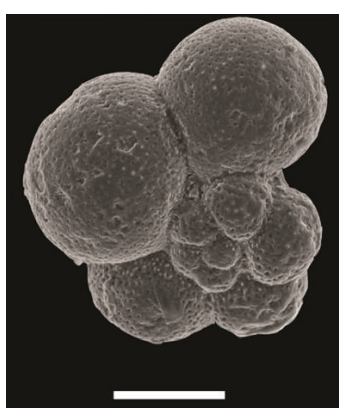

(1)

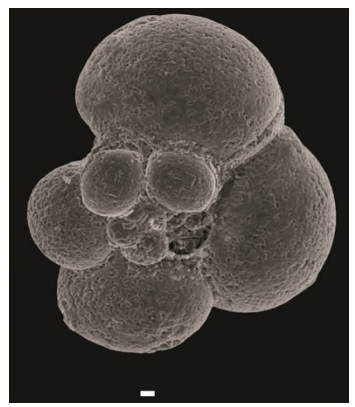

(5a)

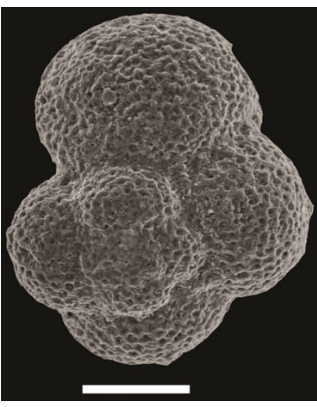

(6b)

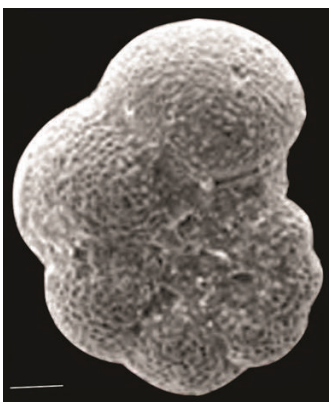

(8c)

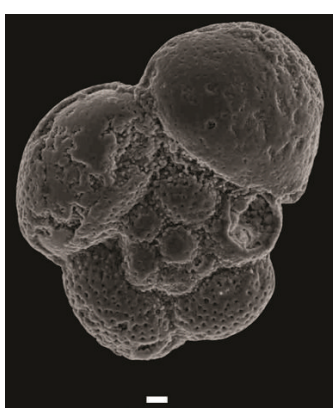

(2)

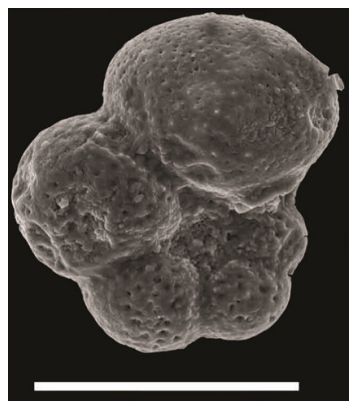

(5b)

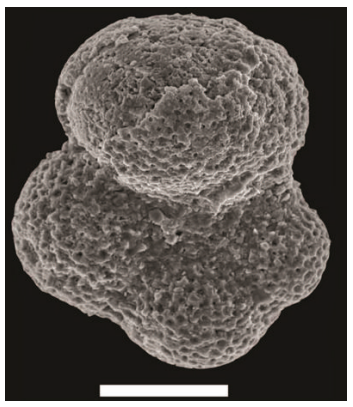

(7)

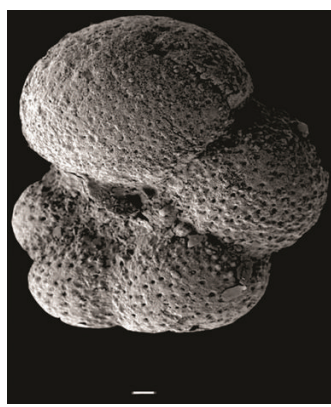

(9a)

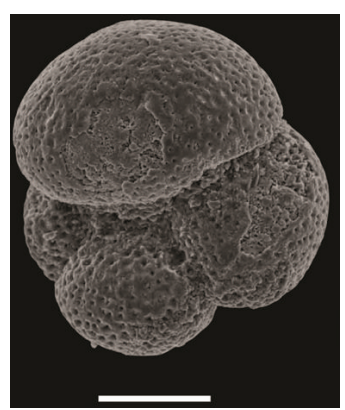

(3)

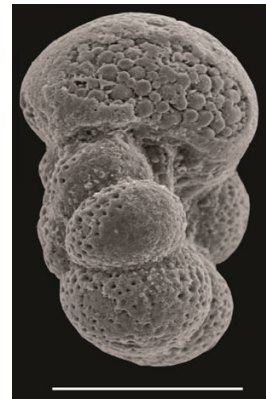

(5c)

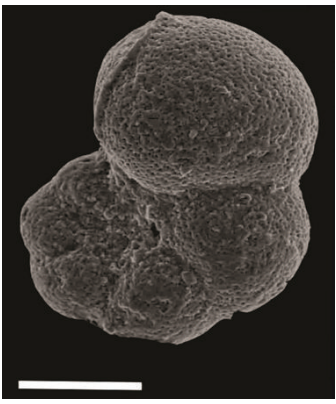

(8a)

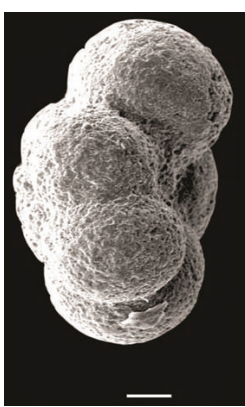

(9b)

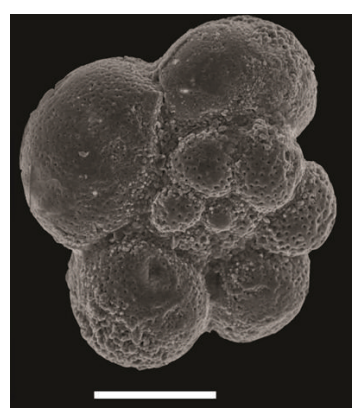

(4)

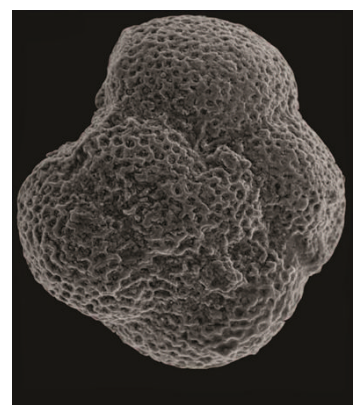

(6a)

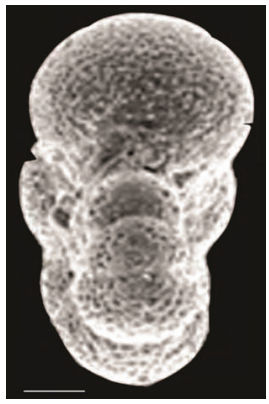

(8b)

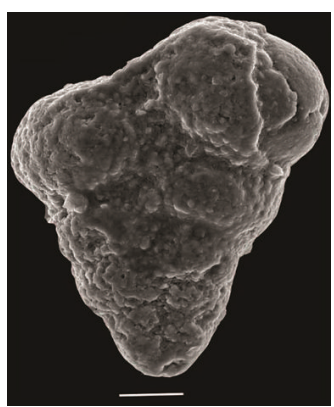

(10)

FIGURE 8: (1) Globanomalina chapmani [32], $100 \mu \mathrm{m}$, (2) Globanomalina compressa [33], $20 \mu \mathrm{m}$, (3) Globanomalina imitata [34], 20 $\mu \mathrm{m},(4)$ Globanomalina ehrenbergi [35], $100 \mu \mathrm{m}$, (5) Globanomalina ovalis [36], (5a), $20 \mu \mathrm{m},(5 \mathrm{~b})$ and (5c), $100 \mu \mathrm{m},(6)$ Parasubbotina variant [34], $100 \mu \mathrm{m}$, (7) Parasubbotina variospira [37], $100 \mu \mathrm{m}$, (8) Pseudohastigerina wilcoxensis [38], $100 \mu \mathrm{m},(9)$ Parasubbotina variospira, 20 $\mu \mathrm{m},(10)$ Chiloguembelina trinitatensis, $20 \mu \mathrm{m}$, [39].

and low-oxygen conditions). This agglutinated foraminifera assemblage is an indication of neritic paleodepth for the Chehel-Kaman Formation in the studied section. Despite of numerous zonal schemes, stratigraphical studies still face with the problems of global correlation of Paleogene deposits between continents and oceans. These stratigraphical problems are mainly related to discontinuities or several dissolution in the Paleogene sequences. Additionally the composition of planktonic foraminifera assembalges is determined by climate and locally restricted environmental conditions. 


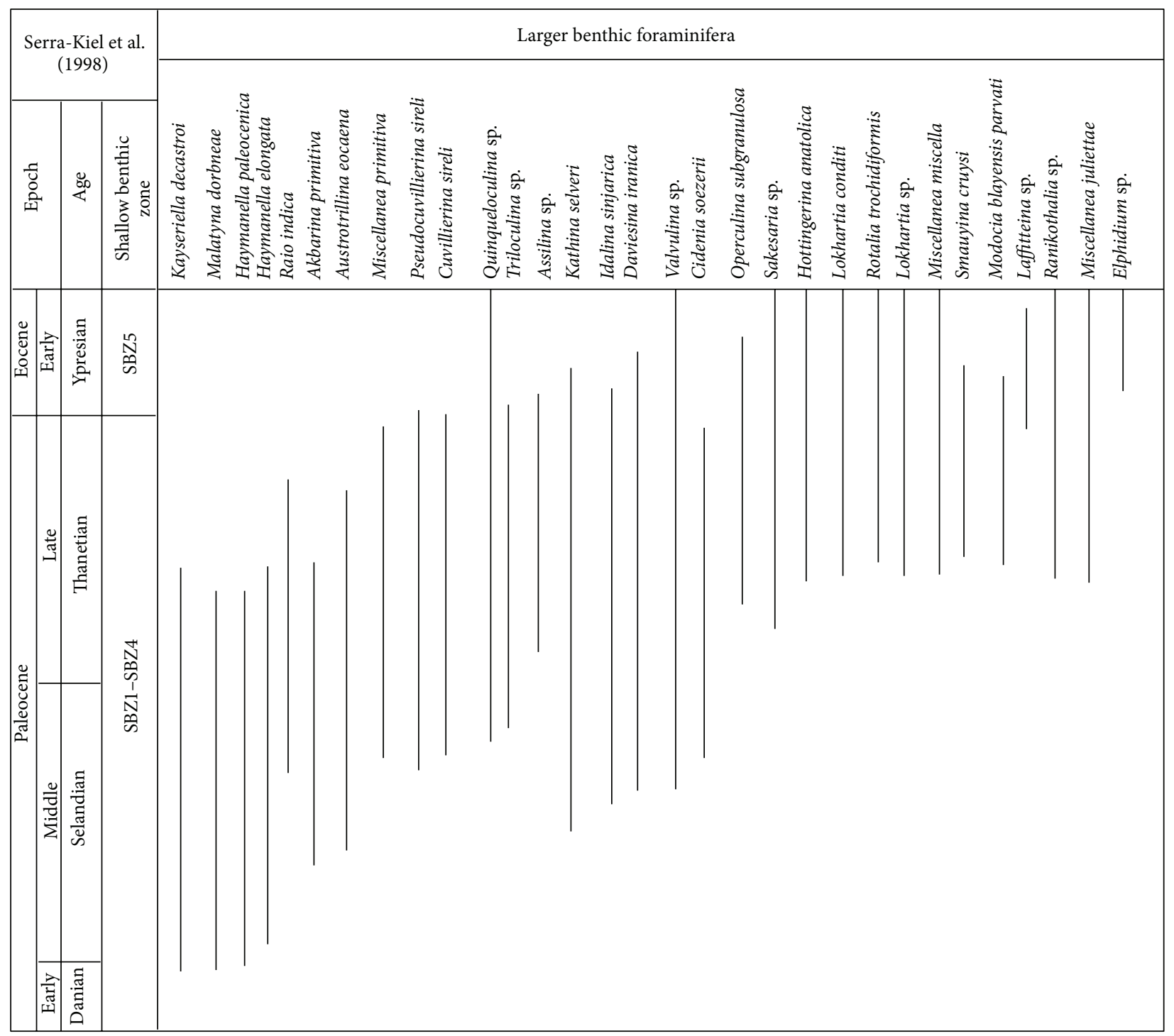

FIGURE 9: Stratigraphic distribution of the larger benthic foraminifera identified in the studied section (Central Kopet-Dagh basin, Karnaveh section).

Therefore the influence of climatic belts and local conditions must be carefully considered in order to understand the composition and distribution of planktonic foraminiferal associations. Chemical and physical factors influencing the presence and distribution of planktonic foraminifera in the ocean waters are salinity, turbidity, currents, and temperature. In this study the absence of Morozovella genus represents a problem to perform standard biozonation. Acarininids and morozovellids have similar ecology, and they need oligotrophic conditions. Interestingly the abundance of larger benthic foraminifera in Kopet-Dagh Basin when ChehelKaman Formation has been deposited confirms the presence of oligotrophic conditions. Consequently there are other reasons and then nutrients which must have determined the absence of Morozovella in this basin, likely input of siliciclastic sediments, clay content, and facies changes. Bolli and Krasheninnikov [30] discussed the problems of Paleogene and Neogene biostratigraphic correlations based on planktonic foraminifera. In particular for the Paleogene, they discussed examples from the Caucasus-Crimea and eastern Mediterranean, where faunal differences are related to climatic and facies changes. Actually, in the Crimea and North Caucasus area there are different assemblages of planktonic foraminiferal species found near each other in the same zone.

Based on studying larger benthic foraminifera (Figure 9), the following taxa have been recognized: Rotalid formular, Daviesina iranica, Valvulina sp., Cuvilierina sireli inan, Laffitteina sp., Hottingerina anatolica, Sakesaria sp., Cidenia soezerii, Pseudocuvillierina sireli, Lokarthia diversa, Ranikothalia sp., Orbitokathina saravensis Sirel, Haymanella paleocenica, Haymanella elongata, Miscellanea juliettae, Miscellanea sp., Miscellanea miscella, Miscellanea primitiva, Akbarina primitiva, Lokarthia sp., Lokarthia conditi, Malatyna dorbneae, Smauyina cruysi, Modocia blayensis, Kathina selveri, Kathina 
sp., Rotalia trochidiformis, Idalina sinjarica, Austrotrillina eocaena, Raoia indica, Quinqueloculina sp., Operculina subgranulosa, Triloculina sp., Biloculina sp., Textularia sp., Spirolina sp., Rotaliidae indent., Assilina granulose, Storrsella haastersi, and Elphidium sp.

Based on the larger benthic foraminifera identifications [20], three Tethyan foraminiferal biozones (SBZ1-SBZ4) spanning from late Danian to late Thanetian interval were recognized in the carbonate of Karnaveh section. The top of the sequence might have been deposited during the Early Eocene based on the identification of planktonic foraminifera. Therefore, based on this study a late danian to early Ypresian age is suggested for the Chehel-Kaman Formation.

\section{Discussion and Conclusions}

Biostratigraphy and sequence stratigraphy of Paleogene sediments in northeastern of Iran (Central part of Kopet-Dagh Basin) have been studied in this paper. Petrographical studies indicate that these sediments may have been deposited in open marine, shoal, lagoon, and tidal flat environments within a shallow carbonate ramp depositional system. Based on sequence stratigraphy analysis within the Chehel-Kaman Formation four depositional sequences have been identified, respectively, bounded by type 2 (within the top of the underlying Pestehleigh Formation), type 1, type 1, and type 2 sequence boundaries. Interpretation of sea level curve in this basin can be correlated with global curves during the early Paleogene. The Paleocene/Eocene boundary has been probably recorded as a thin red paleosol horizon $(\sim 10-15 \mathrm{~cm})$. Biostratigraphic studies based on larger benthic foraminifera and planktonic foraminifera identifications suggest a late Danian to early Ypresian age for these sediments. The absence of Morozovella genus is interpreted as local changes in environments and dissolution that are coincided with the extinction event in many marine successions in the Parathetys.

\section{Acknowledgments}

The authors are grateful and would like to thank Dr. J. Zamagni (Postdam University), Dr. J. Bowen Powel (Miami, Florida), Dr. A. Govindan, and Dr. M. Boukhary for paper revision and constructive comments. They are grateful to Ferdowsi University of Mashhad for the financial supports of this research. They would also like to thank Professor Eustoquio Molina from Zaragoza University. Also they thank Mousavi Zadeh for his invaluable helps during the study. [33], $20 \mu \mathrm{m}$, (3) Globanomalina imitata [34],

\section{References}

[1] J. Zachos, H. Pagani, L. Sloan, E. Thomas, and K. Billups, "Trends, rhythms, and aberrations in global climate $65 \mathrm{Ma}$ to present," Science, vol. 292, no. 5517, pp. 686-693, 2001.

[2] G. J. Bowen, D. J. Beerling, P. L. Koch, J. C. Zachos, and T. Quattlebaum, "A humid climate state during the Palaeocene/Eocene thermal maximum," Nature, vol. 432, no. 7016, pp. 495-499, 2004 .
[3] J. P. Kennett and L. D. Stott, "Abrupt deep-sea warming, palaeoceanographic changes and benthic extinctions at the end of the Palaeocene," Nature, vol. 353, no. 6341, pp. 225-229, 1991.

[4] P. N. Pearson, R. K. Olsson, B. T. Huber, C. Hemleben, and W. A. Berggren, Atlas of Eocene Planktonic Foraminifera, 2005.

[5] S. D'Hondt, J. C. Zachos, and G. Schultz, "Stable isotopic signals and photosymbiosis in late Paleocene planktic foraminifera," Paleobiology, vol. 20, no. 3, pp. 391-406, 1994.

[6] D. C. Kelly, T. J. Bralower, J. C. Zachos, I. P. Silva, and E. Thomas, "Rapid diversification of planktonic foraminifera in the tropical Pacific (ODP Site 865) during the late Paleocene thermal maximum," Geology, vol. 24, no. 5, pp. 423-426, 1996.

[7] R. D. Norris, "Symbiosis as an evolutionary innovation in the radiation of Paleocene planktic foraminifera," Paleobiology, vol. 22, pp. 461-480, 1996.

[8] W. A. Berggren, D. V. Kent, C. C. Swisher III, and M. P. Aubry, "A revised Cenozoic geochronology and chronostratigraphy," in Geochronology, Time Scales and Global Stratigraphic Correlation: A Unified Temporal Framework for an Historical Geology, W. A. Berggren, D. V. Kent, M. P. Aubry, and J. Hardenbol, Eds., vol. 54, pp. 129-212, Society of Economic Paleontologists and Mineralogists, Tulsa, Okla, USA, 1995.

[9] J. I. Canudo, G. Keller, E. Molina, and N. Ortiz, "Planktonic foraminiferal turnover and $\delta 13 \mathrm{C}$ isotopes across the PaleoceneEocene transition at Caravaca and Zumaya, Spain," Palaeogeography, Palaeoclimatology, Palaeoecology, vol. 114, no. 1, pp. 75100, 1995.

[10] M. B. Allen, S. J. Vincent, G. I. Alsop, A. Ismail-zadeh, and R. Flecker, "Late Cenozoic deformation in the South Caspian region: effects of a rigid basement block within a collision zone," Tectonophysics, vol. 366, no. 3-4, pp. 223-239, 2003.

[11] A. Afshar-Harb, The stratigraphy tectonics and petroleum geology of the Kopet-Dagh region, Northeast Iran [Ph.D. thesis], University of London, 1979.

[12] L. A. Buryakovsky, G. V. Chilinger, and F. Aminzadeh, Petroleum Geology of the South Caspian Basin, Gulf Professional Publishing, Boston, Mass, USA, 2001.

[13] M. Alavi, "Tectonostratigraphy synthesis and structural style of the Alborz Mountain system in northern Iran," Journal of Geodynamics, vol. 21, no. 1, pp. 1-33, 1996.

[14] E. Garzanti and M. Gaetani, "Unroofing history of late paleozoic magmatic arcs within the "Turan Plate" (Tuarkyr, Turkmenistan)," Sedimentary Geology, vol. 151, no. 1-2, pp. 67-87, 2002.

[15] A. Kalantari, "Biofacies relationship of the Kopet-Dagh region," Tehran Oil Company Geological Laboratories Publication 3, 1987.

[16] R. Moussavi-Harami and R. L. Brenner, "Geohistory analysis and petroleum reservoir characteristics of Lower Cretaceous (Neocomian) sandstones, Eastern Kopet-Dagh Basin, Northeastern Iran," American Association of Petroleum Geologists Bulletin, vol. 76, no. 8, pp. 1200-1208, 1992.

[17] A. Mahboubi, R. Moussavi-Harami, Y. Lasemi, and R. L. Brenner, "Sequence stratigraphy and sea level history of the upper Paleocene strata in the Kopet-Dagh basin, Northeastern Iran," American Association of Petroleum Geologists Bulletin, vol. 85, no. 5, pp. 839-859, 2001.

[18] R. Aharipour, Microfacies and depositional environment of Tirgan, Sarcheshmeh, Pesteligh and Chehel-Kaman formations in northeast Gonbad Kavoos (west Kopet-Dagh basin) [M.S. thesis], Tarbiat-Moallem University, Tehran, Iran, 1996 (Persian). 
[19] I. Permoli, R. Rettori, and D. Verga, Practical Manual of Paleocene and Eocene Planktonic Foraminifera, 2003.

[20] J. Serra-Kiel, L. Hottinger, E. Caus et al., "Larger foraminiferal biostratigraphy of the Tethyan Paleocene and Eocene," Bulletin de la Société Géologique de France, vol. 169, no. 2, pp. 281-299, 1998.

[21] W. R. Dickinson, L. S. Beord, G. R. Brakenridge, J. L. Erjavec, and P. T. Ryberg, "Provenance of North American Phanerozoic sandstones in relation to tectonic settings," Geological Society of America Bulletin, vol. 94, no. 2, pp. 222-235, 1983.

[22] J. L. Wilson, Carbonate Facies in Geologic History, Springer, New York, NY, USA, 1975.

[23] F. Flugel, Microfacies of Carbonate Rocks-Analysis, Interpretation and Application, Springer, Berlin, Germany, 2010.

[24] B. U. Haq, J. Hardenbol, and P. R. Vail, "Chronology of fluctuating sea level," Science, vol. 235, no. 4793, pp. 1156-1167, 1987.

[25] A. Rahaghi, "Stratigraphy and faunal assemblage of Paleocene Lower Eocene in Iran," Natonal Iranian Oil Company Geological Laboratories Publication 10, 1983.

[26] R. P. Speijer and R. Wagner, "Sea-level changes and black shales associated with the late Paleocene thermal maximum, organic-geochemical and micropaleontologic evidence from the southern Tethyan marg in (Egypt-Israel)," in Catastrophic Events \& Mass Extinctions: Impacts and Beyond, C. Koeberl and K. G. MacLeod, Eds., Geological Society of America Special Paper, pp. 533-549, Geological Society of America, Boulder, Colo, USA, 2002.

[27] Y. O. Gavrilov, E. A. Shcherbinina, and H. Oberhänsli, "Paleocene-Eocene boundary events in the northeastern PeriTethys," Geological Society of America Special Papers, vol. 369, pp. 147-168, 2003.

[28] L. Alegret, S. Ortiz, I. Arenillas, and E. Molina, "Palaeoenvironmental turnover across the Palaeocene/Eocene boundary at the Stratotype section in Dababiya (Egypt) based on benthic foraminifera," Terra Nova, vol. 17, no. 6, pp. 526-536, 2005.

[29] L. Alegret and S. Ortiz, "Global extinction event in benthic foraminifera across the Paleocene/Eocene boundary at the Dababiya Stratotype section," Micropaleontology, vol. 52, no. 5, pp. 433-447, 2006.

[30] H. M. Bolli and V. A. Krasheninnikov, "Problems in paleogene and neogene correlations based on planktonic foraminifera," Micropaleontology, vol. 23, no. 4, pp. 436-452, 1977.

[31] E. Ghasemi-Nejad, H. Sabbaghiyan, and H. Mosaddegh, "Palaeobiogeographic implications of late Bajocian-Late Callovian (Middle Jurassic) dinoflagellatecysts from the Central Alborz Mountains, northern Iran," Journal of Asian Earth Sciences, vol. 43, no. 1, pp. 1-10, 2012.

[32] W. J. Parr, "Upper Eocene foraminifera from the deep borings in King's Park, Perth, Western Australia," Journal of the Royal Society of Western Australia, vol. 24, pp. 69-101, 1938.

[33] H. J. Plummer, "Foraminifera of the midway formation in Texas," University of Texas Bulletin, vol. 2644, no. 1, pp. 1-206, 1926.

[34] N. N. Subbotina, Iskopaemye foraminifery SSSR (Globigerinidy, Khantkenininidy i Globorotaliidy), vol. 76, Trudy Vsesoyznogo Nauchno-Issledovatel'skogo Geologo-razvedochnogo Instituta, 1953.

[35] H. M. Bolli, "The genera Praeglobotruncana, Globotruncana, Rotalipora Abathomphalus in the upper cretaceous of Trinidad," Natural History Museum Bulletin, vol. 1, no. 215, pp. 51-60, 1957.
[36] A. F. M. M. Haque, "The Foraminifera of the ranikot and the laki of the nammal gorge, salt range, Pakistan geological survey," Paleontologia Pakistanica, vol. 1, pp. 1-300, 1956.

[37] D. J. Belford, Tertiary Foraminifera and Age of Sediments, Ok Tedi-Wabag, Papua, New Guinea, vol. 216 of Bureau of Mineral Resources, Geology and Geophysics, Australia Bulletin, Australian Government Publishing Service, 1984, Cushman and Ponton, $100 \mu \mathrm{m} 1932$.

[38] J. A. Cushman and G. M. Ponton, "An Eocene foraminiferal fauna of Wilcox age from Alabama," Contributions From the Cushman Foundation For Foraminiferal Research, vol. 8, pp. 5172, 1932.

[39] J. A. Cushman and H. H. Renz, Eocene, Midway, Foraminifera from Soldado Rock, Trinidad, vol. 18 of Contribution from the Cushman Laboratory for Foraminiferal Research, 1942. 

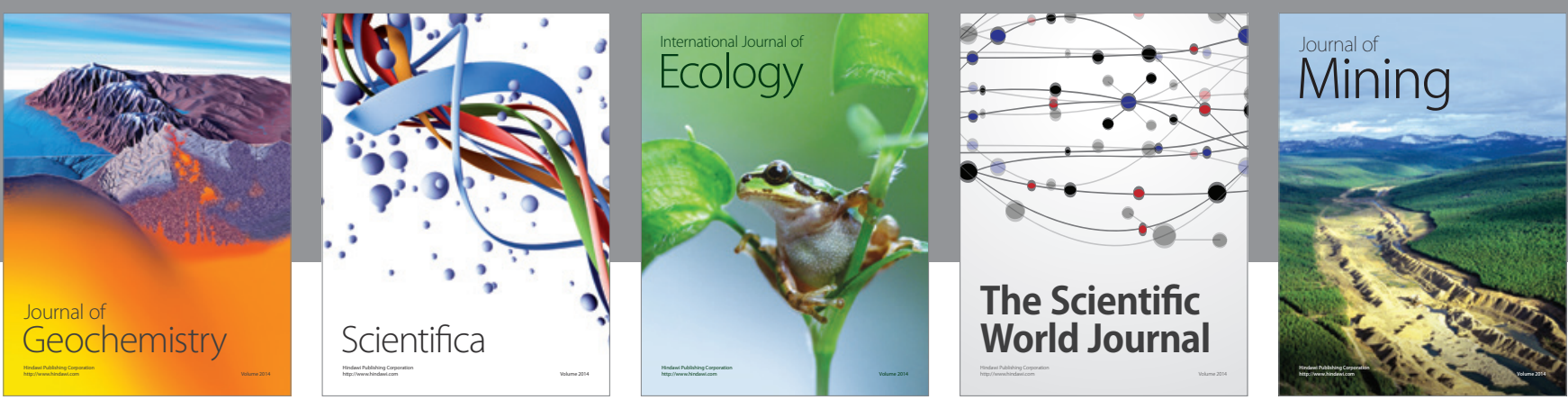

The Scientific World Journal
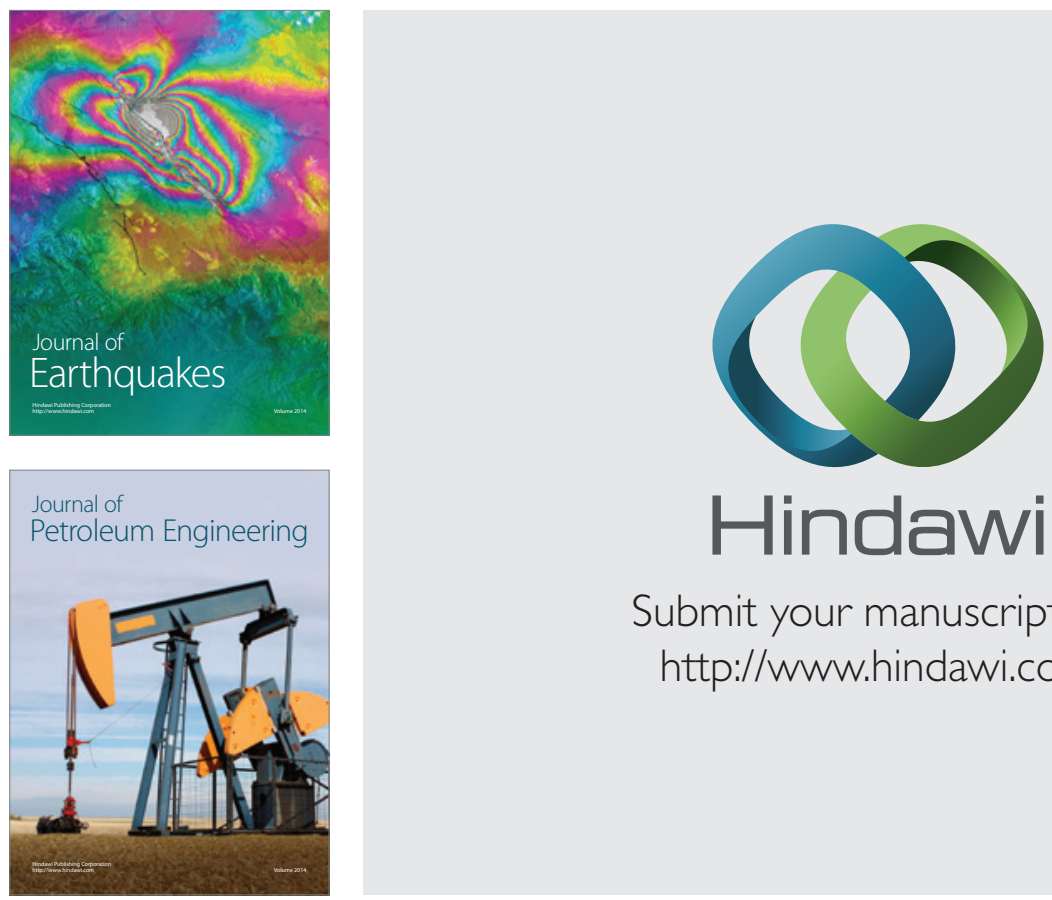

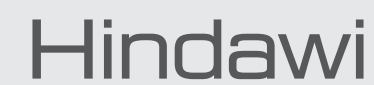

Submit your manuscripts at

http://www.hindawi.com
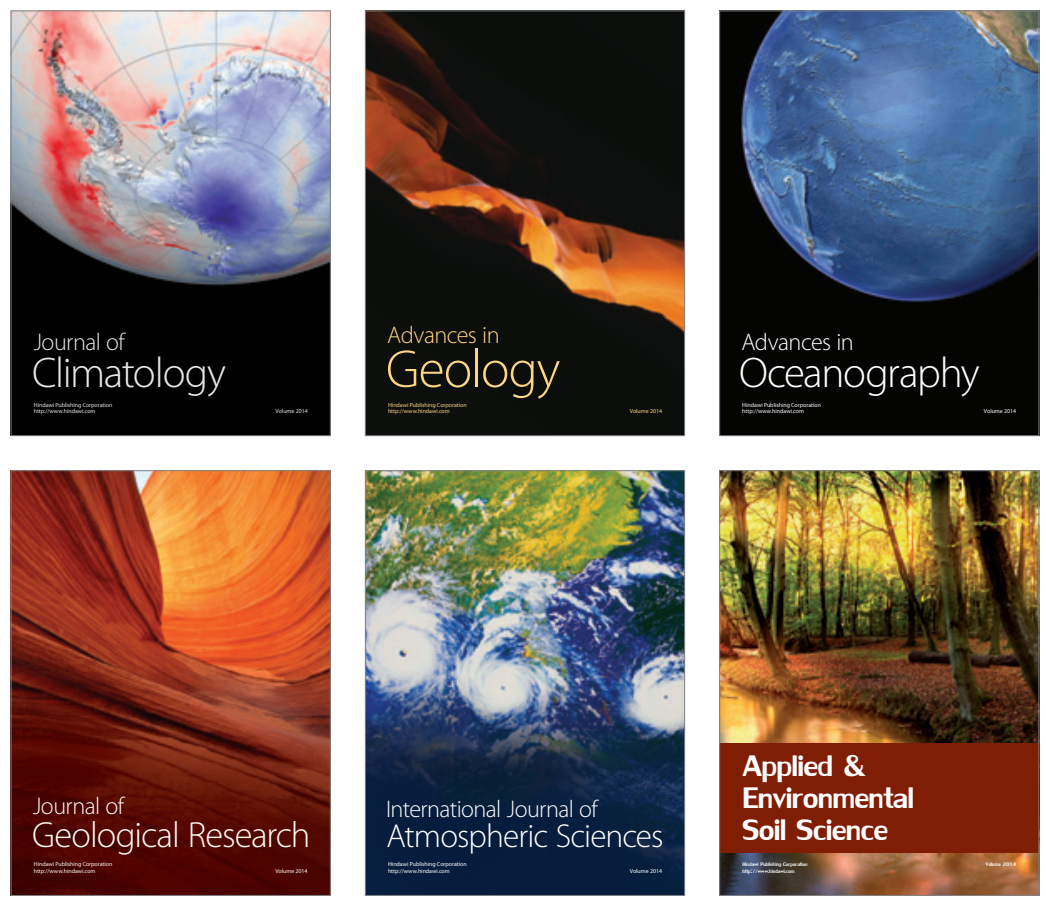
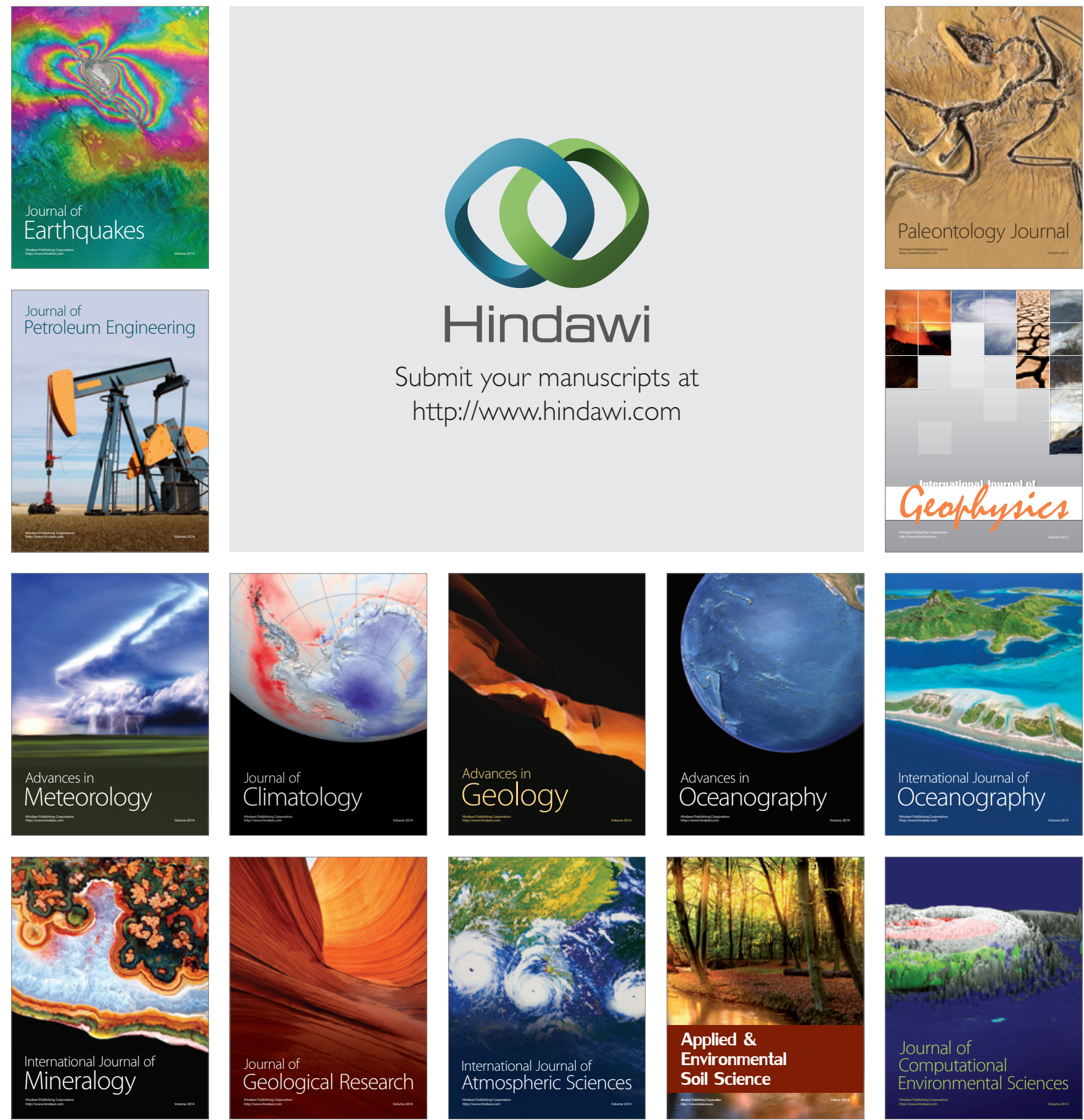